\title{
MEMASTIKAN EFEKTIVITAS IMPLEMENTASI KEBIJAKAN PUBLIK
}

\author{
Y. Gede Sutmasa \\ Fakultas Ilmu Sosial dan Ilmu Politik Universitas Mahendradatta Bali \\ ygdsutmasa@gmail.com
}

\begin{abstract}
Betapa pun baiknya rumusan sebuah kebijakan publik jika gagal diimplementasikan maka kebijakan tersebut tidak ada gunanya. Implementasi kebijakan adalah salah satu sekuen determinan dalam seluruh proses kebijakan publik, karena dia langsung berhubungan dengan kinerja suatu kebijakan, terwujudnya tujuan dan hasil (output dan outcomes). Karenanya, memastikan efektivitas implementasi kebijakan publik menjadi sangat penting, yaitu pertama-tama dengan mehami dengan baik dan benar seluruh prosess kebijakan publik, terlebih faktor-faktor yang memengaruhi implementasi kebijakan. Beberapa faktor yang berpengaruh yaitu: ukuran dan tujuan kebijakan, sumber daya, karakteristik agen pelaksana, sikap/kecenderungan (disposisi) pelskana, komunikasi, lingkungan ekonomi, sosial dan politik, mudah tidaknya masalah yang akan digarap, kemampuan kebijakan menstruktur implementasi secara tepat. Kedua, mengawal implementasi kebijakan publik dengan penuh tanggungjawab melalui monitoring, evaluasi, dan pengganjaran.
\end{abstract}

Kata kunci: Efektivitas, kebijakan publik, implementasi kebijakan

Abstract - No matter how good the formulation of a public policy is, if it fails to be implemented then the policy is useless. Policy implementation is one of the determinant sequences in the entire public policy process, because it is directly related to the performance of a policy, the realization of goals and results (outputs and outcomes). Therefore, ensuring the effectiveness of public policy implementation is very important, that is, first of all by properly and correctly understanding the entire process of public policy, especially the factors that influence policy implementation. Some of the influencing factors are: size and policy objectives, resources, characteristics of implementing agents, attitudes / tendencies (disposition) of operators, communication, economic, social and political environment, whether the problems are easy or not, the ability of policies to structure implementation appropriately. Second, oversee the implementation of public policies with full responsibility through monitoring, evaluation and reward.

Keywords: Effectiveness, public policy, policy implementation

\section{PENDAHULUAN}

Dalam kehidupan bernegara-bangsa, apa pun yang dilakukan oleh Pemerintah dan masyarakat dalam konteks pewujudan tujuan kehidupan bersama selalu didasarkan pada aturan-aturan yang telah ditentukan. Aturan-aturan tersebut dibuat oleh orang-orang atau lembaga-lembaga yang memang diberi otoritas untuk itu berdasarkan peraturan perundang- 
undangan, yaitu Pemerintah baik dalam arti luas maupun dalam arti sempit, sehingga disebut kebijakan publik.

Dengan demikian, kebijakan publik terkait dengan dan mencakup berbagai bidang kehidupan bersama, pada semua urusan pemerintahan dari Pusat hingga Daerah. Pada aras yang sangat luas dan kompleks demikian, kiranya batasan pengertian kebijakan publik yang dirumuskan oleh Thomas R. Dye bisa dipahami. Dye, sebagaimana dikutip Nugroho (2017: 204) mengatakan bahwa kebijakan publik adalah segala sesuatu yang dikerjakan pemerintah, mengapa mereka melakukan, dan hasil yang membuat sebuah kehidupan besama tampil berbeda.

Definisi tersebut secara jelas menegaskan betapa pemerintah memegang peran sangat penting dalam seluruh proses kebijakan publik, dari perumusan, implementasi hingga outcomes-nya. Memang harus diakui, dalam konteks kebijakan publik tersebut, efektivitas sebuah pemerintahan sangat ditentukan. Prof. Michael Porter (dalam Nugroho, 2017: 4) mengatakan:

"What makses government effective? This is among the most important question facing any society, because the failure of government is all too common and often catastrophic. There are numerous examples of countries that have been saddled by bad government policies, poor implememtation, ethical failures, and the inability of government to change when it necessary. The victim are citizens, whose lives and livehoods suffers".
Kebijakan publik yang tidak baik dan gagal diimplementasikan, akan tetap berujung pada gagalnya pemenuhan kebutuhan dan kepentingan masyarakat. Artinya masyarakatlah akhirnya menjadi korban.

Tidak sedikit kebijakan publik yang tidak berhasil diimplementasikan dengan baik - untuk tidak mengatakan gagal. Searah dengan itu, kebijakan-kebijakan yang ketika diimplementasikan akhirnya benar-benar berimpak pada kemaslahatan masyarakat, juga bisa ditemukan di sanasini. Katakanlah kebijakan tata ruang kawasan jalur hijau misalnya. Bisa kita temukan dengan sangat mudahruang-ruang hijau (jalur hijau) sudah beralih fungsi, yang sudah tidak hijau lagi karena diganti dengan "tanaman-tanaman" beton Demikian juga kebijakan tentang jarak bangunan dari bibir pantai. Kemudian kebijakan mode transportasi darat Sarbagita misalnya di Bali yang meredup dan kemudian menguap. Tentu kredo kekurangberhasilan atau kegagalan implementasi kebijakan publik serta output dan outcomes yang dalam kenyataannya terwujud yang sering asimetris dengan tujuan yang diharapkan, bisa dilanjutkan apalagi secara nasional.

Dari seluruh proses kebijakan publik, tahapan yang kemudian secara nyata akan memberi makna positif dan sumbangan ril pada output dan outcomes dari sebuah kebijakan publik adalah implementasi kebijakan itu sendiri. Akib (2010) mengatakan bahwa beberapa penulis menempatkan tahap implementasi kebijakan pada posisi yang berbeda, namun pada prinsipnya setiap kebijakan pubik selalu ditindaklanjuti dengan implementsi kebijakan. Implementasi dianggap sebagai 
wujud utama dan tahap yang sangat menentukan dalam proses kebijakan. Bahkan Edward III, sebagaimana dikutip Akib (2010) mengatakan bahwa tanpa implementasi yang efektif, keputusan pembuatan kebijakan tidak akan berhasil dilaksanakan. Implementasi kebijakan merupakan aktivitas yang terlihat setelah dikeluarkan pengarahan yang sah dari suatu kebijakan yang meliputi upaya mengelola input untuk menghasilkan output dan outcomes bagi masyarakat.

Dengan demikian, dalam rangka mewujudkan pemerintahan yang efektif, memastikan bahwa implementasikebijakan publik dapat dilakukan dengan baik dan sangkil-mangkus, menjadi sangat penting. Untuk itu, pertama-tama harus diketahui faktor-faktor apa saja yang memengaruhi kebijakan publik. Dari pemahaman akan faktor-faktor tersebut akan diketahui pula permasalahan dan hambatan dalam implementasi kebijakan sehingga dengan mencermatinya, solusi bisa dirumuskan untuk keberhasilan implementasi.

\section{PEMBAHASAN}

\section{Memahami Implementasi Kebijakan Publik}

Sebagai sebuah kajian penting dalam ilmu politik, pengertian kebijakan publik secara terus menerus mengalami perkembangan mengikuti semakin kompleksnya dimensi yang terkait dalam praksis kebijakan publik itu sendiri. Perkembangan tersebut sudah barang tentu dimaksudkan untuk mendekatkan dimensi konseptual dengan relitas praksisnya. Salah satu definisi yang cukup komprehensif dikemukakan oleh Carl Friedrich (Agustino, 2008: 7) yaitu bahwa kebijakan publik adalah serangkaian tindakan/kegiatan yang diusulkan oleh seseorang, kelompok, atau pemerintah dalam suatu lingkungan tertentu dimana terdapat hambatan-hambatan (kesulitankesulitan) dan kemungkinan-kemungkinan (kesempatan-kesempatan) dimana kebijakan tersebut diusulkan agar berguna dalam mengatasinya untuk mencapai tujuan yang dimaksud.

Dari rumusan tersebut jelas bahwa untuk mewujudkan suatu maksud atau tujuan tertentu melalui kebijakan publik, maka pertama-tama kebijakan publik itu harus dirumuskan (formulation) lalu dilaksanakan (implementation) dan kemudian dievaluasi (evaluation) seluruh proses perumusan maupunpelaksanaannya. Betapapun baik dan hebatnnya sebuah kebijakan publik dirumuskan, jika tidak diimplementasikan maka kebijakan publik itu tidak lebih dari sekadar macan kertas. Hanya ketika kebijakan itu diimplementasikan maka akan ada hasil (output dan outcomes) yang dirasakan, didapatkan, dinikmati oleh masyarakat atau sasaran kebijakan itu.

Mengacu pada Kamus Webster (dalam Langkai, 2020: 43), implementasi, mengimplementasikan (implementation, to implement) berarti "to provide means for carrying out" (menyediakan alat bantu atau sarana untuk melaksanakan sesuatu); "to give pracitical effect to" (menimbulkan dampak atau berakibat sesuatu). Itu berarti bahwa implementasi kebijakan publik merupakan suatu tindakan berupa intervensi atau manipulasi atas hal/aspek tertentu dalam kehidupan bersama sebagimana tertuang dalam formulasi kebijakan, menggunakan atau memanfaatkan sumberdaya baik manusia, 
finansial, maupun organisasi yang tersedia untuk mencapai tujuan dan sasaran kebijakan, dengan maksud menimbulkan dampak sebagaimana diharapkan. Suatu kebijakan tidak akan ada artinya bila tidak dapat menjawab permasalahan yang ada, kecuali jika kebijakan yang dibuat sebagai kebijakan yang "asal jadi” atau bermuatan kepentingan tertentu sehingga efektivitasnya tidak ada.

Selanjutnya Van Meter dan Van Horn, sebagaimana dikutip Agustino (2008:39) merumuskan implementasi kebijakan sebagai tindakan-tindakan yang dilakukan baik oleh indvidu-individu atau pejabatpejabat atau kelompok-kelompok pemerintah atau swasta yang diarahkan pada tercapainya tujuan-tujuan yang telah digariskan dalam keputusan kebijakan.

Dari pengertian tersebut dapat ditegaskan bahwa implementasi kebijakan selalu mencakup tiga hal, yaitu: 1) adanya tujuan atau sasaran kebijakan; 2) adanya aktivitas atau kegiatan pencapaian tujuan; dan 3) adanya hasil kegiatan (Agustino, ibid.). Jelas sekali bahwa dalam implementasi kebijakan, ada tujuan atau sasaran tertentu yang hendak dicapai atau dipenuhi melalui suatu aksi atau kegiatan yang menghasilkan suatu output dan outcomes tertentu. Lengkai (2020:42) mengatakan bahwa kebijakan diturunkan dalam bentuk program-program, yang kemudian dioperasionalkan sebagai proyek-proyek yang wujudnya adalah kegiatan-kegiatan, baik yang dilakukan oleh pemerintah, masyarakat maupun kerjasama pemerintah dengan masyarakat. Program, proyek dan kegiatan merupakan bagian dari implementasi kebijakan, hasilnya berupa "produk" yang merupakan otput dan outcomes dari suatu kebijakan.
Baik output maupun outcomes adalah luaran dari suatu proses atau kegiatan menghasilkan. Output berkenaan dengan hasil langsung dan/atau segera yang dapat dilihat atau dirasakan, sedangkan outcomes merujuk pada efek, dampak, manfaat, harapan (perubahan), yang biasanya bersifat jangka panjang, dari suatu proses atau kegaitan. Simatupang dan Akib (2011: 6) mengatakan bahwa output kebijakan adalah berbagai hal yang dilakukan oleh pemerintah, misalnya pembangunan dan rehabilitasi jalan raya dan jembatan, pembayaran tunjangan kesejahteraan atau tunjangan profesi. Sedangkan outcomes (dampak) kebijakan menurut Dye sebagaimana dikutip oleh Simatupang dan Akib (ibid.) adalah keseluruhan efek yang ditimbulkan oleh suatu kebijakan dalam kondisi kehidupan nyata. Misalnya, dengan dioperasikannya jalan tol, maka kemudian kemacetan terurai, keamanan dan rasa nyaman berlalu lintas tercipta, dan sebagainya.

Minim atau tidak adanya output dan outcomes dari suatu kebijakan menjadi indikator bahwa kebijakan tersebut tidak terimplementasikan dengan baik atau bahkan gagal diimplementasikan. Maka ini berarti bahwa perubahan atau situasi dan keadaan tertentu yang diharapkan akan terjadi atau terwujud melalui suatu proses dan penetapan kebijakan, hanya akan mungkin jika diimplementasikan. Dengan demikian, bagaimana pun, kebijakan publik memang harus diimplementasikan agar tujuan-tujuan yang digariskan atau output dan outcomes yang diharapkan dapat diwujudkan.

Implementasi kebijakan memamg merupakan tahapan yang sangat penting dari keseluruhan struktur dan proses 
kebijakan. Maka dengan demikian, melalui prosedur dan proses implementasi kebijakan, proses kebijakan secara keseluruhan dapat dimanipulasi sedemikian rupa dalam pencapaian tingkat keberhasilan pencapaian tujuan. Pada aras pemahaman demikian, Udoji sebagaimana dikutip Agustino (2008: 140) mengatakan bahwa pelaksanaan kebijakan adalah sesuatu yang penting bahkan mungkin jauh lebih penting dari pembuatan kebijakan. Kebijakankebijakan hanya akan sekadar berupa impian atau rencana bagus yang tersimpan rapi dalam arsip kalau tidak diimplementasikan. Bahkan Langkai (2020: 45) mengatakan bahwa rencana adalah 20\% keberhasilan, implementasi adalah $60 \%$ nya, sisanya adalah bagaimana implementasi itu dikendalikan.

Pada satu sisi, implementasi kebijakan memang merupakan tahap menentukan dalam seluruh proses kebijakan publik, terutama menyangkut efektivitas kebijakan itu sendiri; dan pada sisi yang lain, dalam kenyataannya mengimplementasikan kebijakan bukanlah sesuatu yang sederhana. Dia bukanlah sekadar bersangkut paut dengan mekanisme penjabaran keputusan-keputusan politik ke dalam prosedur-prosedur rutin lewat saluran-saluran birokrasi, melainkan lebih dari itu. Implementasi kebijakan publik merupakan sesuatu yang sangat complicated. Ia menyangkut masalah konflik, keputusan dan siapa yang memperoleh apa dari kebijakan.

Sejalan dengan itu, Edwards III sebagaimana dipaparkan oleh Faturrahman (2016: 18) mengatakan bahwa implementasi kebijakan publik dalam studi studi kebijakan publik merupakan studi yang sangat "crucial" pada proses kebijakan publik. Yang dimaksudkan adalah betapa pun baiknya suatu kebijakan publik kalau tidak dipersiapkan dan direncanakan dengan baik pada tataran implementasi, maka apa yang menjadi tujuan kebijakan publik tidak akan pernah terwujud. Sebaliknya, bagaimana pun persiapan dan perencanaan implementasi kebijakan publik, kalau suatu kebijakan tidak dirumuskan dengan baik, maka apa yang menjadi tujuan kebijakan publik juga tidak akan bisa diwujudkan.

\section{Faktor-faktor yang Memengaruhi}

Pentingnya peranan implementasi dalam suatu proses kebijakan untuk menciptakan suatu perubahan atau keadaan yang diinginkan, mengharuskan implementasi kebijakan dilaksannakan sedemikian rupa sehingga perubahan atau keadaan yang diinginkan itu terwujud. Maka menjadi keharusan untuk mengindentifikasi secara cermat, mengetahui dan memahami dengan baik dan benar faktor-faktor yang kiranya bisa menjadi penyebab gagal atau tidak berhasilnya suatu kebijakan publik diimplementsikan dengan baik. Sampai di sini, maka yang perlu diketahui terlebih dahulu adalah faktor-faktor yang memengaruhi implementasi kebijakan publik.

Beberapa model pendekatan dalam implementasi kebijakan publik yang dikemukakan oleh para ahli memetakan pula faktor-faktor yang memengaruhi implementasi kebijakan publik, sebagaimana bisa disarikan dari Agustino (2008: 140-161), sebagai berikut:

1. Model Donald Van Metter dan Carl Van Horn 
Pada model Metter dan Horn yang merupakan pendekatan top-down, implementasi merupakan sebuah abstraksi atau performansi yang sengaja dilakukan untuk meraih kinerja implementasi kebijakan publik yang tinggi. Model ini mengandaikan bahwa implementasi kebijakan berjalan secara linear yaitu dari keputusan politik yang tersedia, pelaksana, dan kinerja kebijakan.

Dalam konteks model Metter dan Horn ini, variabel-varibel yang memengaruhi kinerja kebijakan publik adalah:

a. ukuran dan tujuan kebijakan: kinerja implementasi kebijakan dapat diukur tingkat keberhasilannya, jika - dan hanya jika - ukuran dan tujuan kebijakan memang realistis dengan sosio-kultur yang ada di level pelaksana kebijakan;

b. sumber daya: sumber daya manusia adalah sumber daya paling menentukan disamping sumber daya yang lain seperti finansial, waktu;

c. karakteristik agen pelaksana: mencakup organisasi formal dan informal yang harus disesuaikan dengan objek atau entitas tertentu yang diharapkan berubah. Mengubah perilaku manusia misalnya, dibutuhkan karakteristik agen yang tegas, jelas, konsisten;

d. sikap/kecenderungan (disposisi) para pelaksana: sikap penerimaan atau penolakan dari (agen) pelaksana bisa saja terjadi karena acap suatu kebijakan bukanlah formulasi warga setempat yang mengenal betul persoalan dan permsalahan yang dirasakan;

e. komunikasi antarorganisasi dan aktivias pelaksana: semakin baik koordinasi dan komunikasi di antara pihak yang terlibat dalam proses implementasi, maka asumsinya terjadinya kesalahan akan sangat kecil;

f. lingkungan ekonomi, sosial, dan politik: lingkungan sosial, ekonomi, dan politik yang tiak kondusif dapat menjadi akar kegagalan kinerja implementasi kebijakan, demikian sebaliknya.

2. Model Daniel Mazmanian dan Paul Sabatier

Pada model Mazmanian dan Sabatier, peran penting dari implementasi kebijakan publik adalah kemampuannya dalam mengidentifikasi variabel-variabel yang memengaruhi tercapainya tujuan-tujuan formal pada keseluruhan proses implementasi.

Ada tiga kategori besar variabel yang memengaruhi, yaitu:

a. mudah-tidaknya masalah yang akan digarap, yang terdiri dari:

1) kesulitan-kesulitan teknis;

2) keberagaman perilaku yang diatur;

3) persentase totalitas penduduk yang tercakup dalam kelompok sasaran;

4) tingkat dan ruang lingkup perubahan perilaku yang dikehendaki.

b. kemampuan kebijakan menstruktur implementasi secara tepat, meliputi:

1) kecermatan dan kejelasan penjenjangan tujuan-tujuan resmi yang akan tercapai;

2) keterandalan teori kausalitas yang diperlukan;

3) ketetapan alokasi sumber dana;

4) keterpaduan hirarki di dalam lingkungan dan di antara lembagalembaga atau instansi-instansi pelaksana;

5) aturan-aturan pembuat keputusan dari badan-badan pelaksana;

6) kesepakatan para pejabat terhadap tujuan yang termaktub dalam undangundang;

7) akses formal pihak-pihak luar.

c. variabel-variabel di luar undang-undang, terdiri dari:

1) kondisi sosial-ekonomi dan teknologi;

2) dukungan publik; 
3) sikap dan sumber-sumber yang dimiliki kelompok masyarakat;

4) kesepakatan dan kemampuan kepemimpinan para pejabat pelaksana.

3. Model George C. Edward III

Perspektif model pendekatan implementasi Edward III adalah top-down, mendalilkan adanya 4 (empat) variabel sangat menentukan keberhasilan implementasi suatu kebijakan, yaitu: komunikasi, sumber daya, disposisi, dan struktur birokrasi.

a. Komunikasi

Komunikasi yang baik akan memastikan pemahanan yang baik dan benar tentang suatu kebijakan dan dengan demikian implementasinya pun akan bisa dilaksanakan dengan baik dan efektif.

Ada 3 (tiga) indikator yang dapat dipakai mengukur keberhasilan variabel komunikasi:

1) transmisi: penyaluran komunikasi yang baik akan menghasilkan suatu implementasi yang baik pula;

2) kejelasan: komunikasi yang diterima oleh para implementor haruslah jelas dan tidak membingungkan, ketidakjealsan akan selalu menghalangi efektivitas implementasi;

3) konsistensi: perintah yang diberikan dalam pelaksanaan suatu komunikasi haruslah konsisten (tidak berubah-ubah) dan jelas.

b. Sumber daya

Ketiadaan sumber daya sudah barang tentu akan menihilkan pula implementasi kebijakan. Elemen-elemen sumber daya pada model Edward III ini adalah:

1) staf: staf pelaksana kebijakan publik harus tersedia dalam jumlah yang cukup dengan kompetensi memadai;

2) informasi: ada 2 (dua) jenis informasi, yaitu informasi yang berhubungan dengan cara melaksanakan kebijakan, dan informasi mengenai data kepatuhan dari para pelaksana terhadap peraturan dan regulasi pemerintah;

3) wewenang: adalah otoritas formal atau legitimasi bagi para pelaksana untuk memastikan keterukuran dan kepastian suatu implementasi dari aspek legalformal;

4) fasilitas: berupa sarana dan prasarana yang dibutuhkan dan harus ada untuk terwujudnya implementasi suatu kebijakan publik.

c. Disposisi

Disposisi menyangkut sikap dari pelaksana yang memang harus paralel dan akseptif dengan kebijakan publik itu sendiri. Di sini, disposisi tidak hanya berarti mengetahui apa yang harus dilakukan melainkan harus memiliki kemampuan untuk melaksanakannya.

Variabel-variabel disposisi yaitu:

1) pengangkatan birokrasi: pemilihan dan pengangkatan personal pelaksana kebijakan haruslah orang-orang yang memiiki dedikasi pada kebijakan yang telah ditetapkan, lebih khusus lagi pada kepentingan warga;

2) insentif: memanipulasi insentif untuk memengaruh tindakan para pelaksana kebijakan penting dilakukan, misalnya dengan cara menambah keuntungan, sehingga pelaksana kebijakan melaksanakan kebijakan dengan baik karena kepentingan pribadinya (selfinterest) terakomodasi.

d. Struktur birokrasi

Kebijakan publik cenderung merupakan sesuatu yang kompleks sehingga menuntut kerjasama baik dari banyak orang. Ketika struktur birokasi tidak kondusif pada kebijakan tersedia, maka sumber daya menjadi tidak efektif. Birokrasi sebagai 
pelaksana sebuah kebijakan ahrus dapat mendukung kebijakan yang telah diputuskan secara politik dengan jalan melakukan koordinasi dengan baik.

Untuk mendongkrak kinerja struktur birokasi/organisasi ke arah yang lebih baik adalah melalui SOP (standard operating procedure) dan fragmentasi. Salah satu cara melakukan fragmentasi adalah dengan menyebarkan tanggung jawab kegiatankegiatan atau aktivitas pegawai di antara beberapa unit kerja.

\section{Model Merilee S. Grindle}

Pendekatan model Grindle memahami implementasi kebijakan sebagai suatu proses politik dan administratif. Keberhasilan implementasi suatu kebijakan publik dapat diukur dari proses pencapaian hasil akhir (outcomes), yaitu tercapai atau tidaknya tujuan yang ingin diraih.

Pengukuran keberhasilan implementasi kebijakan dapat dilihat dari dua hal, yaitu:

a. proses: apakah pelaksanaan kebijakan sesuai dengan yang ditentukan (designed) dengan merujuk pada aksi kebijakannya;

b. tujuan: yaitu apakah tujuan kebijakan tercapai berdasarkan indikator:

1) impak atau efeknya pada masyarakat secara individu dan kelompok;

2) tingkat perubahan yang terjadi serta penerimaan kelompok sasaran.

Selanjutnya, Grindle juga menyodorkan pemikiran bahwa keberhasilan suatu implementasi kebijakan publik sangat ditentukan oleh tingkat implementabilitas kebijakan itu sendiri, yang terdiri dari:

a. isi kebijakan (content of policy), yang mencakup: terpenuhinya kepentingan, tipe manfaat, derajat perubahan yang ingin dicapai, letak pengambilan keputusan, pelaksana program, sumber-sumber daya yang digunakan. b. konteks kebijakan (context of policy), mencakup: kekuasan, kepentingankepentingan, dan strategi dari aktor yang terlibat; karakteristik lembaga dan rezim yang berkuasa; tingkat kepatuhan dan adanya respons dari pelaksana.

Dari berbagai pendapat tentang model implementasi kebijakan, telah tercermati pula faktor-faktor yang memengaruhi implementasi kebijakan publik, termasuk keberhasilan atau ketidakberhasilannya. Dengan mencermati faktor-faktor tersebut, manipulasi bisa dilakukan terhadapnya, termasuk upaya-upaya dan programprogram yang bersifat preventif sehingga keberhasilan implementasi bisa diwujudkan.

\section{Memastikan Efektivitas Implementasi}

Dengan pemahaman yang baik dan benar tentang implementasi kebijakan publik, mengetahui secara pasti dan terukur faktor-faktor yang memengaruhinya, maka efektivitas implementasi akan bisa dipastikan.

Namun demikian, ketika suatu kebijakan diimplementasikan dalam berbagai program dan aksi untuk mewujudkan tujuan yang telah ditentukan, maka implementasi itu memang harus dikawal. Ini dilakukan oleh setiap orang, lembaga/organisasi yang terlibat di dalamnya. Artinya, akan tidak efektif jika mengawal untuk memastikan kebijakan diimplmentasikan dengan baik, dilakukan oleh mereka yang tidak terlibat dalam seluruh proses implementasi. Karena kalau itu yang terjadi maka orang atau lembaga/organisasi itu tidak lebih dari semacam watch dog, atau bisa saja hanya semacam wasit dalam sebuah pertandingan olah raga. Wasit hanya mengawasi dalam 
rangka ketertiban, tidak bisa menjadi pemain yang menentukan ke arah mana bola dibawa atau dimainkan.

Mengawal implementasi kebijakan publik untuk memastikan efektivitasnya pada dasarnya berarti implementasi itu harus dikendalikan. Dengan mengendalikan, berarti pengendalinya terlibat dalam proses atau kegiatan.

Menurut Nugroho (2017: 779), pengendalian kebijakan, termasuk implementasinya, terdiri dari tiga dimensi, yaitu: monitoring, evaluasi, dan pengganjaran.

1. Monitoring

Monitoring menurut Nugroho (2016: 780) adalah "to watch and check over a period of time". Itu berarti bahwa monitoring tidak hanya mengawasi tetapi juga melakukan pengecekan, pemeriksaan. Monitoring dengan demikian usaha yang dilakukan secara terus-menerus untuk memahami perkembangan bidang-bidang tertentu dari pelaksanaan tugas atau proyek yang sedang dilaksanakan.

Seluruh sekuen dari suatu proses implementasi tidak boleh luput dari pantauan, tahap demi tahap, waktu demi waktu. Tujuannya adalah:

a. menghindarkan terjadinya penyimpangan/kesalahan/keterlambatan, dan jika terjadi segera dapat dibenahi;

b. memastikan proses implementasi sesuai dengan model implementasi yang telah ditentukan;

c. memastikan bahwa implementasi kebijakan selaras dengan arah kinerja kebijakan yang dikehendaki.

Cara-cara atau teknik yang lazim digunakan dalam melakukan monitoring adalah: a. survei lapangan: cara yang sekarang sangat banyak dilakukan apalagi dengan dukungan tekonologi, akurasi dan kecepatannya dapat diandalkan;

b. diskusi kelompok terfokus dengan melibatkan para ahli secara terstruktur;

c. desk monitoring dengan memanfaatkan metode triangulasi.

Apa pun teknik monitoring yang dipilih, tetap saja yang melakukan adalah manusia. Maka, menghindari kelemahan manusiawi, segera harus ditegaskan bahwa profesionalitas, objektivitas dan komitmen menjadi taruhannya. Artinya, meski tampak kegiatan monitoring tampak sepele, sebenarnya dia menjadi filter awal untuk berhasil tidaknya proses selanjutnya.

Orang yang melakukan monitoring mau tidak mau memang harus kompeten di bidang itu. Di samping kompetensi, maka yang bersangkutan juga harus memahami dengan baik proyek/program/kegiatan yang dimonitor; memahami dengan baik pelaksana dan konteks pelaksanaannya; dan memahami serta menguasai metode penelitian cepat (RMA, Rapid Method Assesment), yang syaratnya adalah: cepat menangkap temuan, dan cepat melakukan cara mengungkap temuan.

Sebagaimana diidentifikasi oleh Nugroho (2017: 783), mereka yang melakukan tugas monitoring harus memperhatikan dan mengingat dengan baik hal-hal berikut:

a. proses monitoring tidak diperkenankan mengganggu proses implementasi;

b. petugas monitor tidak diperkenankan melakukan intervensi karena dapat menghilangkan peluang berkembangnya diskresi/inovasi;

c. petugas monitor tidak diperkenankan menyampaikan hasil monitoring kepada yang dimonitor, tetapi kepada atasannya; 
d. petugas monitor tidak diperkenankan mengambil anggota dari pelaksana atau mempunyai hubungan khusus dengan pelaksana.

Dengan memperhatikan aspek-aspek tersebut diharapkan bahwa sekuensia proses implementasi tetap terjaga sebagaimana telah dirancang, sementara objektivitas tetap bisa dipertanggungjawabkan.

2. Evaluasi

Evaluasi merujuk pada tindakan melakukan penilaian atau menilai. Dikaitkan dengan implementasi kebijakan, maka penilaian dilakukan untuk mengetahui sejauh mana efektivitas dan tujuan kebijakan tercapai. Ini berarti mengaharuskan suatu model pembandingan antara apa yang direncanakan atau hasil yang diharapkan terwujud dengan keadaan atau hasil yang terwujud dalam kenyataannya. Dengan demikian, melalui evaluasi dapat ditemukan kesenjangan dan besar-kecilnya kesenjangan antara rencana atau harapan dengan realisasi atau kenyataan.

Kegiatan evaluasi implementasi tidaklah dimaksudkan untuk "mengadili" implementasi dan implementor lalu memberikan hukuman ketika terjadi kekurangan atau kesalahan agar ada efek jera sehingga tidak mengulangi lagi kesalahan, melainkan terutama adalah, sebagaimana diungkapkan oleh Nugroho (2017: 784), menemukan kesenjangan atau kekurangan dan kemudian menutupnya. Dalam bahasa yang lain, Nugroho (2017: 798) menggunakan frase "variasi dalam indikator-indikator kinerja" terkait dengan kesenjangan atau kekurangan dimaksud.

Pertanyaan-pertanyaan yang hendak dijawab dalam implementasi kebijakan adalah: bagaimana kinerja implementasi kebijakan publik?, faktor-faktor apa saja yang menyebabkan variasi dalam indikatorindikator kinerja?, dan bagaimana strategi meningkatkan kinnerja implementasi kebijakan publik?

Jawaban atas pertanyaan-pertanyaan tersebut, yaitu seputar kinerja kebijakan, faktor-faktor yang memengaruhi atau yang menyebabnya keberhasilan atau kekurangberhasilan dan masalah, serta bagaimana mengatasi dan apa yang harus dilakukan, sudah barang tentu merupakan data dan informasi produk evaluasi yang akan sangat berguna untuk memastikan implementasi kebijakan publik.

Agar hasil evaluasi benar-benar objektif dan bermanfaat, evaluator harus memiliki kualitas pemahaman dan keterampilan serta sikap tertentu. Maka syarat sekaligus panduan yang harus dipenuhi dalam melakukan evaluasi adalah (Nugroho, 2017: 799):

a. evaluasi dapat dilakukan oleh internal maupun eksternal pengambil kebijakan;

b. tujuan evaluasi adalah menemukan hal-hal yang strategis untuk meningkatkan kinerja kebijakan;

c. evaluator harus mampu memgambil jarak dari pembuat kebijakan, pelaksana kebijakan, dan target kebijakan;

d. prosedur evauasi harus dapat dipertanggungjawabkan secara metodologi;

e. evaluator haruslah individu atau lembaga yang memiliki karakter profesional, yaitu memiliki kecakapan keilmuan, metodologi, dan beretika;

f. evaluasi dilaksanakan tidak dalam suasana permusuhan.

Hasil sebuah evaluasi implementasi kebijakan selalu akan memetakan hubungan seluruh proses kebijakan dari 
formulasi hingga hasil yang diharapkan. Ini selajan dengan apa yang dikatakan oleh Jones, sebagaimana dikutip oleh Suparno (2017: 15), bahwa implementasi kebijakan adalah kemampuan untuk membentuk hubungan-hubungan lebih lanjut dalam rangkaian sebab-akibat yang menghubungkan tindakan dengan tujuan.

\section{Pengganjaran}

Merunut tujuan pengendalian kebijakan untuk memastikan implementasi berjalan dan terjadi sesuai rancangan, yang tidak bersifat "menghakimi" dan dan begitu saja memberikan hukuman, maka pengganjaran menjadi penting dalam rangka perlakuan yang seimbang antara keberhasilan dan kegagalan/kesalahan.

Kecenderungan yang terjadi selama ini terkait tindakan yang diberikan setelah hasil evaluasi sangat berat ke pendekatan yang bersifat "hukum semata", yang lebih cenderung melihat kesalahan dan kemudian dihukum. Situasi demikian menggiring orang untuk menghindar dari tanggung jawab atau bahkan tidak mau berinisiatif apalagi inovatif dalam implementasi kebijakan demi menghindari hukuman. Ini sudah barang tentu akan sangat melemahkan implementasi kebijakan publik itu sendiri, yang ujung-ujungya sudah pasti masyarakat yang dirugikan.

Yang dapat dilihat selama ini, sanksi diberikan kepada mereka yang tidak mematuhi kebijakan, yaitu masyarakat dan pelaku usaha atau korporasi. Sementara sanksi untuk organisasi publik yang tidak berprestasi sangat lemah, bahkan cenderung tidak ada. Maka tidak mengherankan kemudian kebijakan publik akhirnya menjadi sebatas imbauan saja.
Dengan demikian, perlakuan terhadap kinerja kebijakan harus diberikan secara seimbang. Jika kinerja sesuai dan bagus harus diberikan insentif, apresiasi, jika gagal diberikan disinsentif atau hukuman (reward and punishment). Keduanya dengan kriteria yang jelas.

\section{PENUTUP}

Implementasi kebijakan publik menjadi sekuen yang sangat penting dalam seluruh proses kebijakan, karena hanya dengan implementasi maka tujuan dan hasil yang hendak diwujudkan (output dan outcomes) bisa terwujud.

Memahami dengan baik seluruh proses kebijakan publik, lebih-lebih implementasinya termasuk mengidentifikasi secara cermat, teliti, terukur dan komprehensif faktor-faktor yang memengaruhi implementasi, menjadi keharusan untuk memastikan efektivitas implementasi kebijakan publik itu sendiri.

Mengikuti Van Metter dan Van Horn, Mazmanian dan Sabatier, Edwards III, dan Grindle, dapat disimpulkan faktorfaktor yang memengaruhi impelementasi kebijakan publik adalah: ukuran dan tujuan kebijakan, sumber daya, karakteristik agen pelaksana, sikap/kecenderungan (disposisi) pelskana, komunikasi, lingkungan ekonomi, sosial dan politik, mudah tidaknya masalah yang akan digarap, kemampuan kebijakan menstruktur implementasi secara tepat.

Selanjutnya, ketika suatu kebijakan publik diimplementasikan, dia tidak bisa dibiarkan dan diharapkan otomatis terjadi dan terwujud sebagaimana diharapkan. Untuk memastikan implementasinyabenar- 
benar efektif, dia harus dikawal terus dengan melakukan pengendalian berupa monitoring, evaluasi dan pengganjaran.***

\section{DAFTAR PUSTAKA}

Agustino, Leo. 2008. Dasar-dasar Kebijakan Publik. Bandung: Alfabeta.

Akib, Haedar. 2010. "Implementasi Kebijakan: Apa, Mengapa dan Bagaimana", Jurnal Administrasi Publik, Volume 1 No. 1 Thn. 2010.

Faturrahman, M. 2016. "Faktor Birokrasi dalam Keberhasilan Implementasi Kebijakan Publik". Tarbawi, Volume 2, No. 2, Juli-Desember 2016.

Langkai, Jeane Elisabeth. 2020. Kebijakan Publik, Digital Book. Malang: Seribu Bintang

Mariyati, Tatik. 2013. "Strategi Implementasi Kebijakan Publik dalam Mendorong Percepatan Pengembangan Pengguna Internet", Buletin Pos dan Telekomunikasi Vol. 11 No. 2, Juni 2013.
Nugroho, Riant. 2017. Public Policy, Edisi keenam. Jakarta: Elex Media Komputindo.

Simatupang, Patar dan Akib, Haedar. 2011. "Efektivitas Implementasi dan Dampak Kebijakan dalam Konteks Desentralisasi Pemerintahan", Jurnal Administrasi Publik Vol. II No. 1 Tahun 2011.

Suparno. 2017. Implementasi Kebijakan Publik dalam Praktek. Digital Book. Sidoarjo: Dwiputra Pustaka Jaya.

Tinolah, Rizky Satiti. 2016. "Kebijakan Publik yang Tidak Terimplementasikan: Studi Kasus Peraturan Pemerintah Nomor 74 Tahun 2014 tentang Angkutan Jalan pada Perubahan Kepemilikan Angkutan Umum Milik Perseorangan Menjadi Badan Hukum di Surabaya", Jurnal Kebijakan dan Manajemen Publik, Volume 4, Nomor 1, JanuariApril 2016. 